\title{
ANALISIS KESALAHAN MATEMATIKA MATERI LINGKARAN DITINJAU DARI TINGKAT KEMAMPUAN MATEMATIKA SISWA KELAS VIII SMP NEGERI 12 KENDARI
}

\author{
Jumi Gerhani ${ }^{1)}$, Anwar Bey ${ }^{2)}$, La Ndia $^{3)}$ \\ ${ }^{1)}$ Alumni Jurusan Pendidikan Matematika, ${ }^{2,3)}$ Dosen Jurusan Pendidikan Matematika FKIP \\ Universitas Halu Oleo: email: jumigerhani@gmail.com; abey-unchb@yahoo.co.id; \\ alndifiat@gmai.com
}

\begin{abstract}
Abstrak
Penelitian ini bertujuan untuk mengetahui kesalahan-kesalahan matematika dan persentasenya yang dilakukan siswa kelas VIII SMP Negeri 12 Kendari materi lingkaran serta faktor-faktor penyebab kesalahan tersebut terjadi ditinjau dari tingkat kemampuan matematika siswa. Pengambilan data dalam penelitian ini menggunakan 3 metode yaitu tes, observasi, dan wawancara. Hasil penelitian ini ialah: (1) Kesalahan fakta dengan persentase kesalahan siswa kemampuan matematika rendah sebesar $41,1 \%$, siswa kemampuan matematika sedang sebesar $49,2 \%$, dan siswa kemampuan matematika tinggi sebesar 42,8\%, (2) Kesalahan konsep dengan persentase kesalahan siswa kemampuan matematika rendah sebesar 70,1\%, siswa kemampuan matematika sedang sebesar $35 \%$, dan siswa kemampuan matematika tinggi sebesar 21,4\%, (3) Kesalahan operasi dengan persentase kesalahan siswa kemampuan matematika rendah sebesar 0\%, siswa kemampuan matematika sedang sebesar $8 \%$, dan siswa kemampuan matematika tinggi sebesar $21,4 \%$, (4) Kesalahan prinsip dengan persentase kesalahan siswa kemampuan matematika rendah sebesar 94,1\%, siswa kemampuan matematika sedang sebesar 60,3\% dan siswa kemampuan matematika tinggi sebesar 28,5.
\end{abstract}

Kata Kunci: kesalahan siswa, tingkat kemampuan, kesalahan prinsip

\section{MATHEMATICAL ERROR ANALYSIS OF CIRCLE MATERIAL JUDGING FROM MATHEMATICS ABILITY LEVEL OF GRADE VIII STUDENTS OF SMP NEGERI 12 KENDARI}

\begin{abstract}
This study aims to determine the errors of mathematics and percentage of students of class VIII SMP Negeri 12 Kendari on the material circles and factors causing the error occurs in terms of the level of students' math skills. Data retrieval in this research using 3 method that is test, observation, and interview. The result of this research are: (1) Error of fact with percentage of student error of low math ability equal to $41,1 \%$, student of medium math ability equal to $49,2 \%$, and student of high mathematics ability equal to $42,8 \%$, (2) percentage of student error of low math ability equal to $70,1 \%$, student of medium math ability equal to $35 \%$, and student of high mathematics ability equal to $21,4 \%$. (3) Operational error with percentage of student error of low mathematics ability of $0 \%$, students of medium mathematics ability of $8 \%$, and students of high mathematics ability of $21.4 \%$. (4) Mistake principle with percentage of student error of low mathematics ability equal to $94,1 \%$, student of medium math ability equal to $60,3 \%$ and student of high mathematics ability equal to 28,5 .
\end{abstract}

Keywords: student error, ability level mathematic, mistake principle 


\section{Pendahuluan}

Matematika merupakan salah satu mata pelajaran yang diberikan dalam setiap jenjang pendidikan baik di Sekolah Dasar, Sekolah Menengah Pertama hingga Sekolah Menengah Atas. Matematika juga diajarkan di Perguruan Tinggi. Ada banyak alasan tentang perlunya siswa belajar matematika. Matematika perlu diajarkan kepada siswa karena (1) selalu digunakan dalam segi kehidupan, (2) semua bidang studi memerlukan keterampilan matematika yang sesuai, (3) merupakan sarana komunikasi yang kuat, singkat dan jelas, (4) dapat digunakan untuk menyajikan informasi dalam berbagai keruangan, dan (5) memberikan kepuasaan terhadap usaha memecahkan masalah yang menantang (Abdurrahman, 2003 : 253).

Belajar mengajar matematika pada prinsipnya adalah usaha untuk mencari pengetahuan baru guna mengatasi masalahmasalah yang ada. Menurut Bruner dalam Aisyah (2007 : 5) bahwa belajar matematika adalah belajar mengenai konsep-konsep dan struktur-struktur matematika yang terdapat didalam materi yang dipelajari, serta mencari hubungan antara konsep-konsep dan strukturstruktur matematika itu.

Banyak unsur yang secara bersama-sama dapat mempengaruhi keberhasilan pembelajaran matematika di antaranya adalah guru, siswa, metode pembelajaran dan lingkungan. Ditinjau dari diri siswa, faktor yang mempengaruhi hasil belajar dapat digolongkan menjadi dua yakni faktor internal dan faktor eksternal. Faktor internal merupakan faktor yang ada dalam diri individu yang sedang belajar sedangkan faktor eksternal merupakan faktor yang ada di luar individu. Fakor internal dapat berupa inteligensi, minat, perhatian dan bakat. Faktor ekstern dapat berupa faktor guru, sarana prasarana sekolah, dan faktor masyarakat (Slameto, 2003 : 54). Rendahnya kemampuan individu dalam faktorfaktor tersebut dapat menyebabkan rendahnya hasil belajar matematika yang dapat ditunjukan antara lain melalui kesalahan-kesalahan dan ketidakmampuan siswa dalam menyelesaikan soal matematika.

Kurniasari dalam Ulifa (2014 : 124), kesalahan merupakan suatu bentuk penyimpangan terhadap hal yang benar, prosedur yang ditetapkan sebelumnya, atau penyimpangan dari suatu yang diharapkan. Kamarullah (2005 : 25) mendefinisikan kesalahan adalah penyimpangan dari yang benar atau penyimpangan dari yang telah ditetapkan sebelumnya. Munandar (2002 : 20) mengemukakan kesalahan didefinisikan sebagai penyimpangan terhadap hal yang benar dan sifatnya sistematis, konsisten maupun insidental pada bagian tertentu. Kesalahan matematika ditinjau dari objek matematika yang dikemukakan oleh Begle dalam Rahayu (2015 : 8) terdiri atas empat, yaitu (1) Kesalahan fakta, (2) Kesalahan Konsep, (3) Kesalahan Operasi, dan (4) Kesalahan Prinsip.

Ide manusia tentang matematika berbeda tergantung pada pengalaman dan pengetahuan masing-masing (Abdurrahman, 2003 : 252). Ada individu yang tergolong memiliki kemampuan matematika tinggi, kemampuan matematika sedang dan kemampuan matematika rendah. Sehingga, Kesalahan-kesalahan yang dilakukan oleh setiap individu dalam menyelesaikan soal matematika juga berbedabeda. Kemampuan berasal dari kata "mampu" yang mempunyai arti kesanggupan, kecakapan, atau kekuatan (Poerwadarminta, 2005 : 707). Depdiknas dalam Rofiki (2012 : 38) membuat kriteria tingkat kemapuan matematika siswa dan skala penilaiannya menjadi 3 kategori yaitu kemampuan tinggi jika $80 \leq$ nilai yang diperoleh $\leq 100$, kemampuan sedang jika $65 \leq$ nilai yang diperoleh $<80$, dan kemampuan rendah jika $0 \leq$ nilai yang diperoleh $<65$.

Materi tentang lingkaran, yakni pengukuran sudut pusat, sudut keliling, panjang busur, luas juring dan tembereng dalam lingkaran merupakan salah satu materi pelajaran matematika siswa kelas VIII SMP/Mts. Berdasarkan hasil observasi awal yang dilakukan peneliti pada tanggal 5 Oktober 2016 dan 1 November 2016 di SMP Negeri 12 Kendari melalui wawancara dengan salah satu guru matematika di sekolah tersebut, materi lingkaran tersebut merupakan salah satu materi yang cukup sulit untuk dipahami oleh siswa.

Ada beberapa masalah yang diindikasikan sebagai penyebab materi tentang lingkaran sebagai salah satu materi yang cukup sulit untuk dipahami siswa antara lain kemampuan pemahaman konsep matematika siswa masih kurang, sebagian siswa hanya mengandalkan hafalan, siswa kurang memahami materi prasyarat dan ada bagian dalam materi tersebut yang baru didapat dan dipelajari di kelas VIII.

Uraian di atas mendorong peneliti untuk menganalisis kesalahan matematika siswa ditinjau dari tingkat kemampuan matematika 
siswa pada materi lingkaran yakni pengukuran sudut pusat, sudut keliling, panjang busur, luas juring dan tembereng dalam lingkaran dan mengidentifikasi faktor-faktor yang menyebabkan hal tersebut terjadi.

\section{Metode}

Penelitian ini adalah penelitian eksploratif dengan menggunakan pendekatan deskriptif kualitatif dan deskriptif kuantitatif. Penelitian ini bertujuan untuk mengetahui dan mendeskripsikan kesalahan matematika siswa serta persentasenya ditinjau dari tingkat kemampuan matematika siswa SMP pada materi lingkaran dan faktor-faktor penyebab kesalahan tersebut terjadi. Penelitian ini dilaksanakan di SMP Negeri 12 Kendari pada kelas VIII ${ }_{1}$ dan $\mathrm{VIII}_{2}$ pada bulan Maret sampai Mei 2017.

Populasi dalam penelitian ini adalah siswa kelas VIII SMP Negeri 12 Kendari tahun ajaran 2016/2017 yang tersebar dalam 7 kelas paralel. Sampel dalam penelitian ini menggunakan sampel beralasan (purposive sampling) dimana sebelum melakukan penelitian, peneliti terlebih dahulu membagi siswa dalam 3 kategori berdasarkan kemampuan matematika siswa yakni siswa yang berkemampuan matematika tinggi, sedang dan rendah. Dalam penelitian ini dipilih dua kelas yaitu kelas VIII $_{1}$ dan kelas $\mathrm{VIII}_{2}$ yang memiliki penyebaran kemampuan matematika yang cukup bervariasi berdasarkan nilai ulangan tengah semester siswa.

Pengumpulan data dalam penelitian ini menggunakan tiga metode, yaitu observasi, tes dan wawancara. metode observasi digunakan sebagai salah satu sumber informasi penyebab kesalahan siswa (Sudijono, 2008 : 76). Tes yang diberikan dilakukan uji validitas panelis.Tes ini bertujuan untuk mengungkapkan kelemahan atau bagian yang kurang dipahami oleh siswa. Metode wawancara yang digunakan adalah wawancara semi terstrukur yang dilakukan setelah pemberian tes. Data penelitian ini diperoleh dari observasi selama proses pembelajaran matematika, tes untuk mengetahui pemahaman siswa dalam materi yang telah diajarkan dan data hasil wawancara antara peneliti dengan siswa dan guru yang bersangkutan.

Analisis data dalam penelitian ini adalah analisis deskriptif secara kualitatif dan kuantitatif. Data dideskripsikan secara kuantitatif dalam bentuk persentase. Analisis data kuantitatif dilakukan untuk mengetahui persentase kesalahan siswa berdasarkan tingkat kemampuan matematika siswa pada materi dengan rumus :

$$
P=\frac{R}{N} \times 100 \%
$$

dimana :

$$
\begin{aligned}
& P=\text { Persentase jawaban salah } \\
& R=\text { Banyak siswa yang melakukan } \\
& \quad \text { kesalahan } \\
& N=\text { Banyak siswa menjawab }
\end{aligned}
$$

Data dideskripsikan secara kualitatif melalui kata-kata tertulis. Pengecekan keabsahan data kualitatif dilakukan dengan cara triangulasi. Menurut Lexy J. Moleong (2006 : 330), triangulasi adalah teknik pemeriksaan keabsahan data yang memanfaatkan sesuatu yang lain di luar data itu untuk keperluan pengecekan atau sebagai pembanding terhadap data itu. Triangulasi dalam penelitian ini adalah triangulasi metode yaitu dengan membandingkan data hasil tes yang diverifikasi dengan wawancara, dan observasi (Hidayat, $2013: 4$ ). Analisis data penelitian ini secara kulitatif menurut Milles dan Huberman dilakukan secara interaktif melalui proses reduksi, penyajian data dan kesimpulan (Sugiyono, 2011: 246).

\section{Hasil}

1. Hasil Analisis Observasi

a. Observasi Guru Mengajar

Observasi dilakukan pada saat guru memberikan materi lingkaran yakni pengukuran sudut pusat, sudut keliling, luas juring, panjang busur dan tembereng. Guru memulai pembelajaran dengan membagikan buku paket dan memberitahu siswa tentang pembelajaran yang akan dipelajari. Sebelum menjelaskan mengenai materi yang akan dipelajari, guru selalu mengingatkan materi yang berkaitan dengan lingkaran yang telah dipelajari sebelumnya. Selanjutnya guru menjelaskan tujuan pembelajaran dan memberikan motivasi kepada siswa.

Secara umum, metode yang digunakan guru adalah metode ceramah dan tanya jawab. Metode ceramah digunakan untuk menjelaskan materi pelajaran dan metode tanya jawab digunakan saat guru menjelaskan dalam menyelesaikan soal. Sesekali juga guru membagi kelompok dalam mengerjakan soal latihan yang selanjutnya perwakilan kelompok maju ke depan untuk menyelesaikan soal. Guru sering 
terlambat masuk ke ruangan kelas sehingga proses belajar mengajar menjadi kurang efektif dari waktu yang seharusnya. Meskipun secara umum cara mengajar guru cukup profesional.

b. Observasi Kegiatan Belajar Siswa

Observasi terhadap siswa dilakukan pada saat siswa menerima pelajaran materi lingkaran. Sebelum memulai pelajaran, siswa selalu berdoa menurut agama dan kepercayaan mereka masing-masing. Pada umumnya siswa memperhatikan guru yang sedang menjelaskan materi pelajaran terutama siswa berkemampuan matematika tinggi. Siswa berkemampuan matematika sedang dan rendah terkadang tidak memperhatikan penjelasan guru. Mereka sibuk mencoret-coret kertas atau berbicara dengan temannya. Namun setelah diingatkan mereka kembali memperhatikan penjelasan guru. Siswa berkemampuan matematika tinggi dan sedang mencatat apa yang diberikan guru di papan tulis sedangkan siswa berkemampuan matematika rendah jarang mencatat materi pelajaran.

Keaktifan siswa dalam bertanya kepada guru mengenai hal-hal yang belum mereka ketahui sangatlah kurang. Hanya sesekali siswa berkemampuan matematika tinggi dan sedang bertanya mengenai tulisan guru yang kurang jelas. Pada umumnya siswa akan menjawab pertanyaan-pertanyaan yang membutuhkan jawaban serentak.

Pada saat guru meminta siswa mengerjakan soal latihan, siswa berkemampuan matematika tinggi bisa mengerjakannya dengan baik dibandingkan dengan siswa kemampuan matematika sedang dan rendah. Umumnya siswa tidak memiliki buku paket atau buku pedoman selain buku yang diberikan dari sekolah. Hanya ada beberapa siswa berkemampuan matematika sedang yang membawa buku paket lain tetapi tidak dibaca ketika sedang belajar. Mereka lebih terpaku pada buku yang dibagikan oleh guru.

\section{Hasil Analisis Tes}

a. Deskripsi Hasil Tes

Kesalahan matematika yang dilakukan siswa diketahui melalui pemberian tes kepada siswa. Tes diberikan kepada siswa kelas $\mathrm{VIII}_{1}$ dan $\mathrm{VIII}_{2}$ dengan jumlah siswa sebanyak 64 orang. Pada saat pemberian tes, siswa yang hadir sebanyak 46 siswa yang terdiri dari 25 siswa kelas VIII $_{1}$ dan 21 siswa kelas VIII $_{2}$. Tes yang diberikan terdiri dari 3 butir soal.

\section{Soal Nomor 1}

Perhatikan Gambar 1 berikut. Diketahui O adalah titik pusat lingkaran dan besar $\angle \mathrm{BDC}=$ $72^{\circ}$. Tentukanlah besar $\angle \mathrm{BAC}, \angle \mathrm{BOC}$ dan $\angle \mathrm{OBC}$ ?

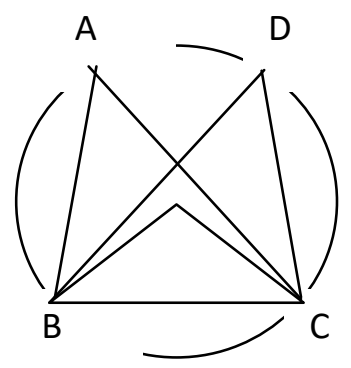

Gambar 1

Soal nomor 1 adalah soal yang dalam penyelesaiannya membutuhkan penguasaan konsep lingkaran yang meliputi sifat sudut keliling "Besar sudut-sudut keliling yang menghadap diameter lingkaran adalah $90^{\circ}$ " dan hubungan sudut pusat dan sudut keliling "Besar sudut pusat adalah dua kali besar sudut keliling yang menghadap busur yang sama, atau besar sudut keliling adalah setengah besar sudut pusat yang menghadap busur yang sama". Siswa juga harus memahami konsep sudut dalam segitiga. Siswa yang menjawab soal nomor 1 sebanyak 46 siswa dimana siswa yang melakukan kesalahan matematika sebanyak 37 siswa. Berdasarkan hasil jawaban siswa diperoleh deskripsi kesalahan siswa pada tabel 1 sebagai berikut. 
Tabel 1

Deskripsi Kesalahan Jawaban Siswa pada Soal Nomor 1

\begin{tabular}{|c|l|}
\hline No. & \multicolumn{1}{|c|}{ Deskripsi Kesalahan Siswa } \\
\hline 1. & $\begin{array}{l}\text { Siswa salah dalam menerapkan sifat sudut keliling "Besar sudut-sudut keliling yang } \\
\text { menghadap diameter panjang busur yang sama adalah sama besar" }\end{array}$ \\
\hline 2. & $\begin{array}{l}\text { Siswa salah dalam menerapkan hubungan sudut pusat dan sudut keliling "Besar sudut } \\
\text { pusat adalah dua kali besar sudut keliling yang menghadap busur yang sama, atau } \\
\text { besar sudut keliling adalah setengah besar sudut pusat yang menghadap busur yang } \\
\text { sama" }\end{array}$ \\
\hline 3. & Siswa melakukan kesalahan operasi misalnya $2 \times 72^{\circ}=142^{\circ}$ \\
\hline 4. & Siswa salah menerapkan konsep sudut dalam segitiga \\
\hline 5. & Siswa salah fakta dalam memberikan simbol derajat \\
\hline 6. & $\begin{array}{l}\text { Siswa salah dalam memasukan data yang tidak sesuai dengan soal misalnya } 71 \\
\text { menjadi } 72\end{array}$ \\
\hline 7. & Kasus khusus : tidak dijawab \\
\hline
\end{tabular}

Soal nomor 2

Perhatikan Gambar 2 berikut. Diketahui luas persegi ABCD adalah $196 \mathrm{~cm}^{2}$ dan besar $\angle \mathrm{POQ}$ $=60^{\circ}$, Tentukanlah panjang busur minor PQ dan luas juring $\mathrm{OPQ}$ ?

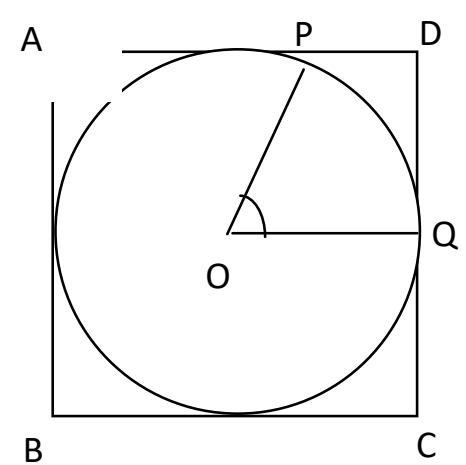

Gambar 2

Soal nomor 2 adalah soal yang dalam penyelesaiannya membutuhkan penguasaan konsep lingkaran yang meliputi konsep panjang busur dan konsep luas juring. Siswa juga harus memahami konsep luas bangun persegi. Siswa yang menjawab soal nomor 2 sebanyak 24 siswa dimana siswa yamg melakukan kesalahan sebanyak 23 siswa. Berdasarkan hasil jawaban siswa diperoleh deskripsi kesalahan siswa pada tabel 2 sebagai berikut.

Deskripsi Kesalahan Jawaban Siswa pada Soal Nomor 2

\begin{tabular}{|l|l|}
\hline No. & \multicolumn{1}{|c|}{ Deskripsi Kesalahan Siswa } \\
\hline 1. & $\begin{array}{l}\text { Siswa salah dalam menerapkan konsep panjang busur PQ = } \\
\frac{\angle P O Q}{360^{0}} \times \text { keliling lingkaran }=\frac{\angle P O Q}{360^{0}} \times 2 \pi r\end{array}$ \\
\hline 2. & $\begin{array}{l}\text { Siswa salah dalam menerapkan konsep luas juring POQ }=\frac{\angle P O Q}{360^{0}} \times \text { lua slingkaran }= \\
\frac{\angle P O Q}{360^{\circ}} \times \pi r^{2}\end{array}$ \\
\hline 3. & Siswa melakukan kesalahan operasi misalnya 2 $\times 1=8$ \\
\hline 4. & Siswa salah menerapkan konsep luas bangun persegi \\
\hline 5. & Siswa salah dalam menentukan jari-jari lingkaran \\
\hline 6. & Siswa salah dalam memberikan satuan panjang dan satuan luas \\
\hline 7. & Siswa tidak menuliskan satuan panjang dan satuan luas \\
\hline 8. & Siswa salah dalam memasukan data yang tidak sesuai dengan soal \\
\hline 9. & Kasus khusus : tidak dijawab \\
\hline
\end{tabular}


Soal Nomor 3

Hitunglah luas tembereng pada gambar berikut. Diketahui panjang jari-jari lingkaran adalah $14 \mathrm{~cm}$ !

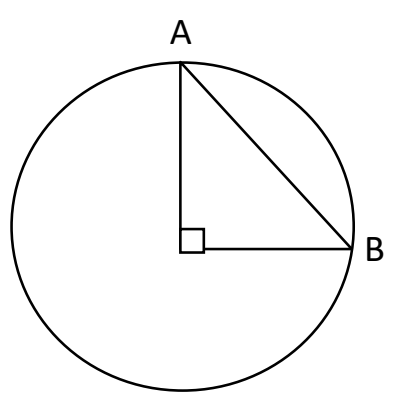

Deskripsi Kesalahan Jawaban Siswa pada Soal Nomor 3

Gambar 3 tabel 3 sebagai berikut.

Tabel 3
Soal nomor 3 adalah soal yang dalam penyelesaiannya membutuhkan penguasaan konsep lingkaran yang meliputi konsep luas juring dan konsep luas bangun segitiga. Siswa yang menjawab soal nomor 3 sebanyak 24 siswa dimana yang melakukan kesalahan matematika sebanyak 19 siswa. Berdasarkan hasil jawaban siswa diperoleh deskripsi kesalahan siswa pada

\begin{tabular}{|c|c|}
\hline No. & Deskripsi Kesalahan Siswa \\
\hline 1. & $\begin{array}{l}\text { Siswa salah dalam menerapkan konsep luas juring } \mathrm{AOB}=\frac{\angle A O B}{360^{\circ}} \times \text { luaslingkaran }= \\
\frac{\angle A O B}{360^{\circ}} \times \pi r^{2}\end{array}$ \\
\hline 2. & Siswa salah dalam menerapkan konsep luas bangun segitiga $=\frac{1}{2} \times a t$ \\
\hline 3. & Siswa melakukan kesalahan operasi misalnya $22 \times 7=156$ \\
\hline 4. & Siswa salah dalam memberikan satuan luas yaitu satuannya menjadi “o” \\
\hline 5. & Siswa tidak menuliskan satuan luas \\
\hline 6. & Siswa salah dalam memasukan data yang tidak sesuai dengan soal \\
\hline 7. & Kasus khusus : tidak dijawab \\
\hline
\end{tabular}

Berdasarkan deskripsi kesalahan yang dilakukan siswa dirangkum bentuk-bentuk kesalahan siswa yang akan digunakan dalam proses analisis data. Bentuk-bentuk tersebut adalah sebagai berikut.

1. Kesalahan Fakta dalam penelitian ini dikategorikan menjadi 2 bentuk yaitu :

a. Bentuk F1 : Jika siswa salah atau tidak menuliskan notasi, satuan panjang, luas dan satuan sudut.

b. Bentuk F2 : Jika siswa memasukan data yang tidak sesuai dengan soal.

2. Kesalahan Konsep dalam penelitian ini dikategorikan menjadi 5 bentuk yaitu :

a. Bentuk K1 : Jika siswa melakukan kesalahan dalam memahami/menerapkan konsep sifat sudut keliling "Besar sudutsudut keliling yang menghadap busur yang sama adalah sama besar “

b. Bentuk K2 : Jika siswa melakukan kesalahan dalam memahami/menerapkan konsep hubungan sudut pusat dan sudut keliling "Besar sudut pusat adalah dua kali besar sudut keliling yang menghadap busur yang sama atau besar sudut keliling adalah setengah besar sudut pusat yang menghadap busur yang sama"

c. Bentuk K3 : Jika siswa melakukan kesalahan dalam memahami/menerapkan konsep panjang busur $\mathrm{PQ}=$ $\frac{\angle P O Q}{360^{\circ}} \times$ keliling lingkaran $=$ $\frac{\angle P O Q}{360^{\circ}} \times 2 \pi r \quad$ konsep luas juring $\mathrm{POQ}=\frac{\angle P O Q}{360^{\circ}} \times$ luaslingkaran $=$ $\frac{\angle P O Q}{360^{\circ}} \times \pi r^{2}$

$\mathrm{PQ}=\frac{\angle P O Q}{360^{\circ}} \times$ Keliling lingkaran $=$ $\frac{\angle P O Q}{360^{\circ}} \times 2 \pi r$

d. Bentuk K4 : Jika siswa melakukan kesalahan dalam memahami/menerapkan konsep luas juring $\mathrm{POQ}=$ $\frac{\angle P O Q}{360^{\circ}} \times$ luaslingkaran $=$ $\frac{\angle P O Q}{360^{\circ}} \times \pi r^{2}$ 
3. Kesalahan Operasi dalam penelitian ini disimbolkan dengan $\mathrm{O}$ ketika siswa salah dalam melakukan operasi perhiungan aljabar.

4. Kesalahan Prinsip dalam penelitian ini dikategorikan menjadi 2 bentuk yaitu :

a. Bentuk S1 : Jika siswa melakukan kesalahan dalam memahami/menerapkan konsep sudut dalam segitiga

b. Bentuk S2 : Jika siswa melakukan kesalahan dalam memahami/menerapkan konsep luas bangun persegi

c. Bentuk S3 : Jika siswa melakukan kesalahan dalam memahami/menerapkan konsep luas bangun segitiga

Tabel 4

Kesalahan Fakta Siswa Kelas Subjek Penelitian

\begin{tabular}{|c|c|c|c|c|c|c|c|c|c|}
\hline \multirow{2}{*}{$\begin{array}{c}\text { Tingkat } \\
\text { Kemampuan } \\
\text { Matematika } \\
\text { Siswa }\end{array}$} & \multirow[t]{2}{*}{$\begin{array}{c}\text { Jumlah } \\
\text { Siswa }\end{array}$} & \multirow[t]{2}{*}{$\begin{array}{c}\text { Butir } \\
\text { Soal }\end{array}$} & \multirow{2}{*}{$\begin{array}{c}\text { Siswa } \\
\text { yang } \\
\text { Menjawab }\end{array}$} & \multirow{2}{*}{$\begin{array}{c}\text { Siswa } \\
\text { yang } \\
\text { Tidak } \\
\text { Menjawab }\end{array}$} & \multirow{2}{*}{$\begin{array}{l}\text { Siswa } \\
\text { Salah } \\
\text { Fakta }\end{array}$} & \multicolumn{2}{|c|}{$\begin{array}{c}\text { Bentuk } \\
\text { Kesalahan } \\
\text { Fakta } \\
\end{array}$} & \multicolumn{2}{|c|}{$\begin{array}{c}\% \\
\text { Salah } \\
\text { Fakta }\end{array}$} \\
\hline & & & & & & $\mathrm{F} 1$ & $\mathrm{~F} 2$ & $\mathrm{~F} 1$ & $\mathrm{~F} 2$ \\
\hline \multirow{3}{*}{ Rendah } & \multirow{3}{*}{12} & 1 & 12 & 0 & 5 & 4 & 1 & \multirow{3}{*}{$29,4 \%$} & \multirow{3}{*}{$11,7 \%$} \\
\hline & & 2 & 3 & 9 & 1 & 1 & 0 & & \\
\hline & & 3 & 2 & 9 & 1 & 0 & 1 & & \\
\hline \multirow{3}{*}{ Sedang } & \multirow{3}{*}{29} & 1 & 29 & 0 & 8 & 7 & 3 & \multirow{3}{*}{$44,4 \%$} & \multirow{3}{*}{$15,8 \%$} \\
\hline & & 2 & 16 & 13 & 11 & 11 & 2 & & \\
\hline & & 3 & 18 & 11 & 12 & 10 & 5 & & \\
\hline \multirow{3}{*}{ Tinggi } & \multirow{3}{*}{5} & 1 & 5 & 0 & 1 & 1 & 0 & \multirow{3}{*}{$42,8 \%$} & \multirow{3}{*}{$0 \%$} \\
\hline & & 2 & 5 & 0 & 3 & 3 & 0 & & \\
\hline & & 3 & 4 & 1 & 2 & 2 & 0 & & \\
\hline
\end{tabular}

Dari Tabel 4 menunjukan bahwa kesalahan fakta bentuk F1 paling banyak dilakukan oleh siswa kemampuan matematika sedang yakni sebesar $44,4 \%$ dan paling sedikit dilakukan oleh siswa kemampuan matematika
5. Kasus khusus yakni tidak menjawab.

b. Analisis Kesalahan Matematika Siswa Ditinjau dari Tingkat Kemampuan Matematika Siswa

a) Kesalahan Fakta

Persentase kesalahan fakta dan kesalahan fakta menurut bentuk-bentuk kesalahannya dirangkum pada Tabel 4 sedangkan gambaran detail sebaran kesalahan fakta pada setiap soal menurut bentuknya disajikan pada Gambar 1. rendah yakni sebesar 29,4\%. Kesalahan fakta bentuk F2 paling banyak dilakukan oleh siswa kemampuan matematika sedang yakni sebesar $15,8 \%$ dan paling sedikit dilakukan oleh siswa matematika tinggi yakni sebesar $0 \%$.

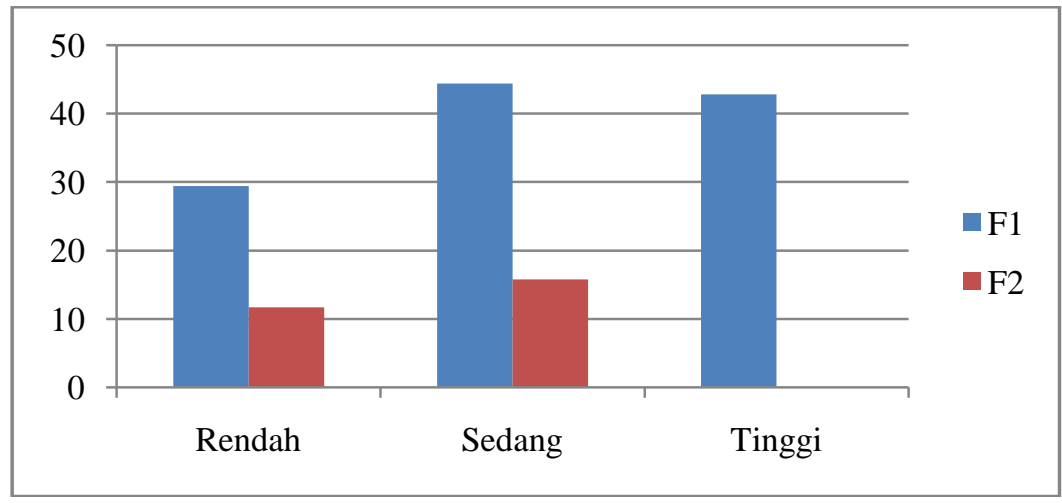

Gambar 1. Kesalahan Fakta Siswa Kelas Subjek Penelitian 
Berdasarkan Gambar 1 terlihat bahwa siswa yang memiliki kemampuan matematika rendah, sedang dan tinggi paling banyak melakukan kesalahan fakta bentuk F1 yakni salah dalam menuliskan satuan atau notasi dengan persentase secara berturut-turut sebesar $29,4 \%, 44,4 \%$ dan $42,8 \%$. b) Kesalahan Konsep

Persentase kesalahan konsep dan kesalahan konsep menurut bentuk-bentuk kesalahannya dirangkum pada Tabel 5 sedangkan gambaran detail sebaran kesalahan konsep pada setiap soal menurut bentuknya disajikan pada Gambar 2.

Tabel 5

Kesalahan Konsep Siswa Kelas Subjek Penelitian

\begin{tabular}{|c|c|c|c|c|c|c|c|c|c|c|c|c|c|}
\hline \multirow{2}{*}{$\begin{array}{c}\text { Tingkat } \\
\text { Kemampuan } \\
\text { Matematika } \\
\text { Siswa }\end{array}$} & \multirow{2}{*}{$\begin{array}{l}\text { Jumlah } \\
\text { Siswa }\end{array}$} & \multirow{2}{*}{$\begin{array}{l}\text { Butir } \\
\text { Soal }\end{array}$} & \multirow{2}{*}{$\begin{array}{c}\text { Siswa } \\
\text { yang } \\
\text { Menjawab }\end{array}$} & \multirow{2}{*}{$\begin{array}{c}\text { Siswa } \\
\text { yang } \\
\text { Tidak } \\
\text { Menjawab }\end{array}$} & \multirow{2}{*}{$\begin{array}{c}\text { Siswa } \\
\text { Salah } \\
\text { Konsep }\end{array}$} & \multicolumn{4}{|c|}{$\begin{array}{l}\text { Bentuk Kesalahan } \\
\text { Konsep }\end{array}$} & \multicolumn{4}{|c|}{$\begin{array}{c}\% \\
\text { Salah } \\
\text { Konsep }\end{array}$} \\
\hline & & & & & & $\begin{array}{l}\mathrm{K} \\
1 \\
\end{array}$ & $\begin{array}{l}K \\
2 \\
\end{array}$ & $\begin{array}{l}K \\
3 \\
\end{array}$ & $\begin{array}{l}K \\
4 \\
\end{array}$ & $\mathrm{~K} 1$ & K2 & K3 & K4 \\
\hline \multirow{3}{*}{ Rendah } & \multirow{3}{*}{12} & 1 & 12 & 0 & 7 & 4 & 7 & 0 & 0 & \multirow{3}{*}{$\begin{array}{c}23,5 \\
\%\end{array}$} & \multirow{3}{*}{$\begin{array}{c}41,1 \\
\%\end{array}$} & \multirow{3}{*}{$\begin{array}{c}17,6 \\
\%\end{array}$} & \multirow{3}{*}{$\begin{array}{c}29,4 \\
\%\end{array}$} \\
\hline & & 2 & 3 & 9 & 3 & 0 & 0 & 3 & 3 & & & & \\
\hline & & 3 & 2 & 9 & 2 & 0 & 0 & 0 & 2 & & & & \\
\hline \multirow{3}{*}{ Sedang } & \multirow{3}{*}{29} & 1 & 29 & 0 & 8 & 6 & 8 & 0 & 0 & \multirow{3}{*}{$\begin{array}{c}9,5 \\
\%\end{array}$} & \multirow{3}{*}{$\begin{array}{c}12,6 \\
\%\end{array}$} & \multirow{3}{*}{$\begin{array}{c}11,1 \\
\%\end{array}$} & \multirow{3}{*}{$\begin{array}{c}20,6 \\
\%\end{array}$} \\
\hline & & 2 & 16 & 13 & 10 & 0 & 0 & 7 & 9 & & & & \\
\hline & & 3 & 18 & 11 & 4 & 0 & 0 & 0 & 4 & & & & \\
\hline \multirow{3}{*}{ Tinggi } & \multirow{3}{*}{5} & 1 & 5 & 0 & 1 & 0 & 1 & 0 & 0 & \multirow{3}{*}{$0 \%$} & \multirow{3}{*}{$\begin{array}{c}7,1 \\
\%\end{array}$} & \multirow{3}{*}{$\begin{array}{c}7,1 \\
\%\end{array}$} & \multirow{3}{*}{$\begin{array}{c}14,2 \\
\%\end{array}$} \\
\hline & & 2 & 5 & 0 & 2 & 0 & 0 & 1 & 2 & & & & \\
\hline & & 3 & 4 & 1 & 0 & 0 & 0 & 0 & 0 & & & & \\
\hline
\end{tabular}

Dari Tabel 5 menunjukan bahwa kesalahan konsep paling banyak dilakukan oleh siswa kemampuan matematika rendah baik kesalahan konsep K1, K2, K3 dan K4. Siswa matematika sedang juga melakukan kesalahan

konsep pada setiap bentuk kesalahan konsep. Siswa matematika tinggi melakukan kesalahan konsep pada benuk K2, K3 dan K4 sedangkan pada kesalahan konsep bentuk K1 tidak terjadi kesalahan konsep.

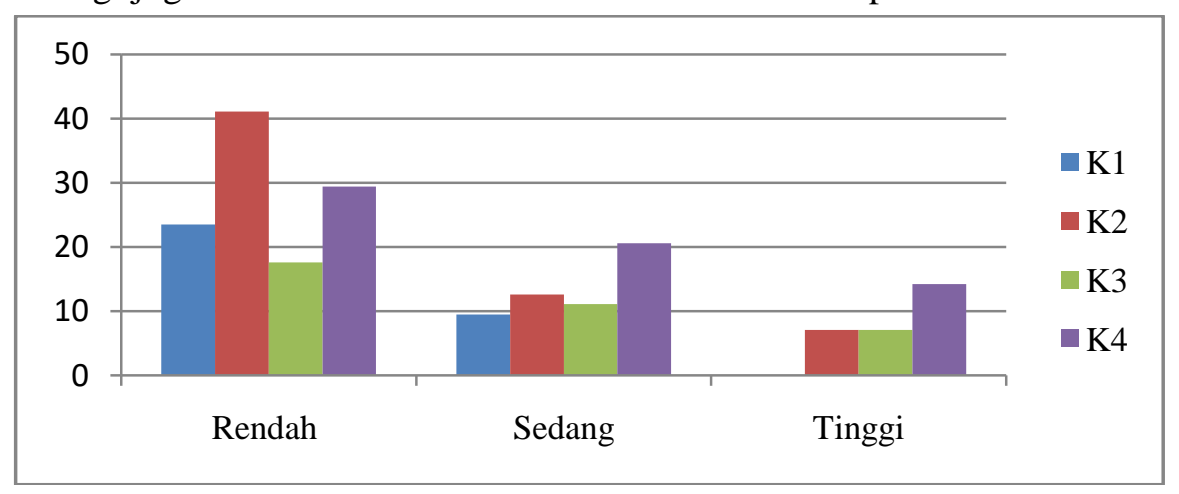

Gambar 2. Kesalahan Konsep Siswa Kelas Subjek Penelitian

Berdasarkan Gambar 2 terlihat bahwa siswa kemampuan matematika rendah paling banyak melakukan kesalahan konsep bentuk K2 yakni salah dalam memahami konsep hubungan sudut pusat dan sudut keliling dengan persentase sebesar $41,1 \%$ dan paling sedikit melakukan kesalahan konsep bentuk K3 yakni salah dalam memahami konsep panjang busur dengan persentase sebesar $17,6 \%$. Siswa kemampuan matematika sedang dan tinggi paling banyak melakukan kesalahan konsep bentuk K4 yakni salah dalam memahami konsep luas juring dengan persentase secara berturutturu sebesar 20,6\% dan 14,2\%. Siswa kemampuan matematika sedang paling sedikit melakukan kesalahan konsep bentuk K1 yakni salah dalam memahami konsep sifat sudut keliling dengan persentase sebesar 9,5\%. 
Persentase kesalahan operasi dirangkum pada Tabel 6 .

Tabel 6

Kesalahan Operasi Siswa Kelas Subjek Penelitian

\begin{tabular}{|c|c|c|c|c|c|c|c|}
\hline $\begin{array}{c}\text { Tingkat } \\
\text { Kemampuan } \\
\text { Matematika } \\
\text { Siswa } \\
\end{array}$ & $\begin{array}{c}\text { Jumlah } \\
\text { Siswa }\end{array}$ & $\begin{array}{l}\text { Butir } \\
\text { Soal }\end{array}$ & $\begin{array}{c}\text { Siswa } \\
\text { yang } \\
\text { Menjawab }\end{array}$ & $\begin{array}{c}\text { Siswa } \\
\text { yang } \\
\text { Tidak } \\
\text { Menjawab } \\
\end{array}$ & $\begin{array}{l}\text { Siswa } \\
\text { Salah } \\
\text { Operasi }\end{array}$ & $\begin{array}{c}\% \\
\text { Salah } \\
\text { operasi }\end{array}$ & $\begin{array}{c}\% \\
\text { Salah } \\
\text { Operasi }\end{array}$ \\
\hline \multirow{3}{*}{ Rendah } & \multirow{3}{*}{12} & 1 & 12 & 0 & 0 & $0 \%$ & \multirow{3}{*}{$0 \%$} \\
\hline & & 2 & 3 & 9 & 0 & $0 \%$ & \\
\hline & & 3 & 2 & 9 & 0 & $0 \%$ & \\
\hline \multirow{3}{*}{ Sedang } & \multirow{3}{*}{29} & 1 & 29 & 0 & 0 & $0 \%$ & \multirow{3}{*}{$8 \%$} \\
\hline & & 2 & 16 & 13 & 0 & $0 \%$ & \\
\hline & & 3 & 18 & 11 & 5 & $5 \%$ & \\
\hline \multirow{3}{*}{ Tinggi } & \multirow{3}{*}{5} & 1 & 5 & 0 & 1 & $1 \%$ & \multirow{3}{*}{$21,4 \%$} \\
\hline & & 2 & 5 & 0 & 0 & $0 \%$ & \\
\hline & & 3 & 4 & 1 & 2 & $2 \%$ & \\
\hline
\end{tabular}

Dari Tabel 6 menunjukan bahwa kesalahan operasi paling banyak dilakukan oleh siswa kemampuan matematika tinggi dengan persentase sebesar $21,4 \%$ dan siswa kemampuan matematika sedang dengan persentase $7,9 \%$. Siswa kemampuan matematika rendah tidak melakukan kesalahan operasi. d) Kesalahan Prinsip

Persentase kesalahan prinsip dan kesalahan prinsip menurut bentuk-bentuk kesalahannya dirangkum pada Tabel 7 sedangkan gambaran detail sebaran kesalahan prinsip pada setiap soal menurut bentuknya disajikan pada Gambar 3.

Tabel 7

Kesalahan Prinsip Siswa Kelas Subjek Penelitian

\begin{tabular}{|c|c|c|c|c|c|c|c|c|c|c|c|}
\hline \multirow{2}{*}{$\begin{array}{c}\text { Tingkat } \\
\text { Kemampuan } \\
\text { Matematika } \\
\text { Siswa }\end{array}$} & \multirow[t]{2}{*}{$\begin{array}{c}\text { Jumlah } \\
\text { Siswa }\end{array}$} & \multirow[t]{2}{*}{$\begin{array}{l}\text { Butir } \\
\text { Soal }\end{array}$} & \multirow{2}{*}{$\begin{array}{c}\text { Siswa } \\
\text { yang } \\
\text { Menjawab }\end{array}$} & \multirow{2}{*}{$\begin{array}{c}\text { Siswa } \\
\text { yang } \\
\text { Tidak } \\
\text { Menjawab } \\
\end{array}$} & \multirow{2}{*}{$\begin{array}{l}\text { Siswa } \\
\text { Salah } \\
\text { Prinsip }\end{array}$} & \multicolumn{3}{|c|}{$\begin{array}{c}\text { Bentuk } \\
\text { Kesalahan } \\
\text { Prinsip }\end{array}$} & \multicolumn{3}{|c|}{$\begin{array}{c}\% \\
\text { Salah } \\
\text { Prinsip }\end{array}$} \\
\hline & & & & & & $\mathrm{S} 1$ & S2 & S3 & $\mathrm{S} 1$ & S2 & S3 \\
\hline \multirow{3}{*}{ Rendah } & \multirow{3}{*}{12} & 1 & 12 & 0 & 7 & 4 & 7 & 0 & \multirow{3}{*}{$\begin{array}{c}64,7 \\
\%\end{array}$} & \multirow{3}{*}{$\begin{array}{c}17,6 \\
\%\end{array}$} & \multirow{3}{*}{$\begin{array}{r}11,7 \\
\%\end{array}$} \\
\hline & & 2 & 3 & 9 & 3 & 0 & 0 & 3 & & & \\
\hline & & 3 & 2 & 9 & 2 & 0 & 0 & 0 & & & \\
\hline \multirow{3}{*}{ Sedang } & \multirow{3}{*}{29} & 1 & 29 & 0 & 8 & 6 & 8 & 0 & \multirow{3}{*}{$\begin{array}{c}26,9 \\
\%\end{array}$} & \multirow{3}{*}{$\begin{array}{c}22,2 \\
\%\end{array}$} & \multirow{3}{*}{$\begin{array}{r}11,1 \\
\%\end{array}$} \\
\hline & & 2 & 16 & 13 & 10 & 0 & 0 & 7 & & & \\
\hline & & 3 & 18 & 11 & 4 & 0 & 0 & 0 & & & \\
\hline \multirow{3}{*}{ Tinggi } & \multirow{3}{*}{5} & 1 & 5 & 0 & 1 & 0 & 1 & 0 & \multirow{3}{*}{$\begin{array}{r}7,1 \\
\%\end{array}$} & \multirow{3}{*}{$\begin{array}{c}21,4 \\
\%\end{array}$} & \multirow{3}{*}{$0 \%$} \\
\hline & & 2 & 5 & 0 & 2 & 0 & 0 & 1 & & & \\
\hline & & 3 & 4 & 1 & 0 & 0 & 0 & 0 & & & \\
\hline
\end{tabular}

Dari Tabel 7 menunjukan bahwa kesalahan prinsip paling banyak dilakukan oleh siswa kemampuan matematika rendah dan sedang pada bentuk S1 yakni salah dalam memahami konsep sudut dalam segitiga dengan persentase secara berturu-turut sebesar $64,7 \%$ dan 7,\%. Secara umum, semua siswa melakukan kesalahan prinsip tetapi siswa matematika tinggi tidak melakukan kesalahan prinsip pada bentuk S3 yakni salah dalam konsep luas segitiga. 


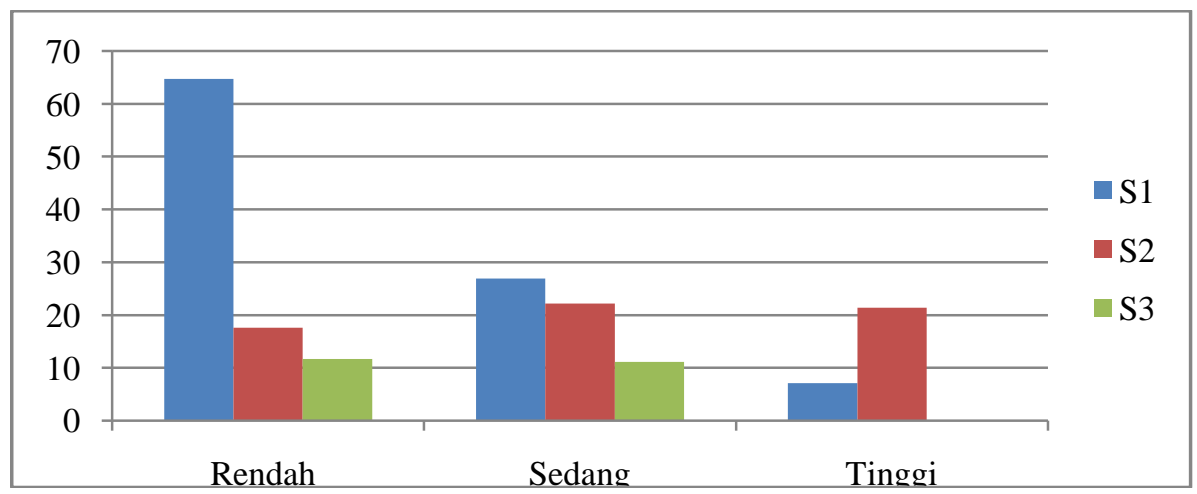

Gambar 3. Kesalahan Prinsip Siswa Kelas Subjek Penelitian

Berdasarkan Gambar 3 terlihat bahwa siswa kemampuan matematika rendah dan sedang paling banyak melakukan kesalahan prinsip bentuk S1 yakni salah dalam memahami konsep sudu dalam segitiga dengan persentase secara berturut-turut sebesar $64,7 \%$ dan $26,9 \%$ serta paling sedikit melakukan kesalahan prinsip bentuk S3 yakni salah dalam memahami konsep luas segitiga dengan persentase secara berturutturut sebesar $11,7 \%$ dan $11,1 \%$. Siswa kemampuan matematika tinggi paling banyak melakukan kesalahan prinsip bentuk S2 yakni salah dalam memahami konsep luas persegi dengan persentase sebesar $21,4 \%$ serta tidak terjadi kesalahan prinsip pada bentuk S3 yakni salah dalam memahami konsep luas segitiga.

\section{Tabel 8}

Persentase Kesalahan Matematika Siswa Subjek Penelitian Ditinjau dari Tingkat Kemampuan Matematika Siswa

\begin{tabular}{|c|c|c|c|}
\hline \multirow{2}{*}{$\begin{array}{c}\text { Persentase } \\
\text { Kesalahan }\end{array}$} & \multicolumn{3}{|c|}{ Tingkat Kemampuan Matematika Siswa } \\
\cline { 2 - 4 } & Rendah & Sedang & Tinggi \\
\hline Fakta & $41,1 \%$ & $49,2 \%$ & $42,8 \%$ \\
\hline Konsep & $70,1 \%$ & $35 \%$ & $21,4 \%$ \\
\hline Operasi & $0 \%$ & $8 \%$ & $21,4 \%$ \\
\hline Prinsip & $94,1 \%$ & $60,3 \%$ & $28,5 \%$ \\
\hline
\end{tabular}

Berdasarkan Tabel 8 terlihat bahwa siswa kemampuan matematika rendah melakukan kesalahan paling banyak pada kesalahan prinsip yakni sebesar 94,1\% dan paling sedikit kesalahan operasi yakni $0 \%$. Siswa kemampuan matematika sedang melakukan kesalahan paling banyak pada kesalahan prinsip yakni sebesar $60,3 \%$ dan paling sedikit kesalahan operasi yakni $8 \%$. Siswa kemampuan matematika tinggi melakukan kesalahan paling banyak pada kesalahan fakta yakni sebesar $42,8 \%$ dan paling sedikit kesalahan konsep dan operasi yakni $21,4 \%$.

\section{Pembahasan}

Kesalahan fakta yang dilakukan siswa dalam penelitian ini adalah kesalahan dalam menuliskan notasi dan satuan serta salah dalam memasukan data yang tidak sesuai dengan soal. Kesalahan fakta siswa kemampuan matematika rendah sebesar $41,1 \%$ dengan bentuk-bentuk kesalahan siswa yang dilakukan adalah (1) Kesalahan dalam menuliskan notasi atau satuan sebesar 29,4\% dan (2) kesalahan memasukan data yang tidak sesuai dengan soal sebesar $11,7 \%$. Kesalahan fakta siswa kemampuan matematika sedang sebesar $49,2 \%$ dengan bentuk-bentuk kesalahan siswa yang dilakukan adalah (1) Kesalahan dalam menuliskan notasi atau satuan sebesar $44,4 \%$ dan (2) kesalahan memasukan data yang tidak sesuai dengan soal sebesar 15,8\%. Kesalahan fakta siswa kemampuan matematika tinggi sebesar 42,8\% dengan bentuk-bentuk kesalahan siswa yang dilakukan adalah (1) Kesalahan dalam menuliskan notasi atau satuan sebesar $42,8 \%$ dan 


\section{Jurnal Penelitian Pendididikan Matematika Volume 7 No.2 Mei 2019}

(2) kesalahan memasukan data yang tidak sesuai dengan soal sebesar $0 \%$.

Berdasarkan hasil tes, siswa SH1 yang memiliki tingkat kemampuan matematika rendah melakukan kesalahan dengan tidak menuliskan simbol "o" dalam besar sudut pada soal nomor 1. Berdasarkan hasil wawancara dengan siswa SH1, hal ini terjadi karena siswa tersebut terburu-buru dalam mengerjakan soal.

Siswa ES1 yang memiliki tingkat kemampuan matematika sedang melakukan kesalahan dengan tidak menuliskan satuan pada panjang busur pada soal nomor 2 serta salah dalam menuliskan satuan luas tembereng yakni $\mathrm{cm}$ seharusnya $\mathrm{cm}^{2}$ pada soal nomor 3 . Berdasarkan hasil wawancara dengan siswa ES1, hal ini terjadi karena siswa tersebut terburu-buru dalam mengerjakan soal. Akan tetapi, setelah ditanya lebih lanjut ternyata siswa ES1 tidak memahami satuan apa yang dimaksud dalam soal. Siswa MM1 yang memiliki tingkat kemampuan matematika tinggi juga melakukan kesalahan dengan tidak menuliskan satuan panjang busur dan luas juring pada soal nomor 2 serta luas tembereng pada nomor soal 3. Hal ini terjadi karena siswa tersebut lebih mementingkan nilai jawaban akhir dan mengabaikan dalam menuliskan satuan yang dianggapnya tidak terlalu penting.

Kesalahan konsep siswa dalam penelitian ini adalah salah dalam menggunakan konsep materi lingkaran yakni salah dalam konsep sifat sudut keliling, hubungan sudut keliling dan sudut pusat, panjang busur dan luas juring. Kesalahan konsep siswa kemampuan matematika rendah sebesar $70,1 \%$ dengan bentuk-bentuk kesalahan siswa yang dilakukan adalah (1) Kesalahan dalam konsep sifat sudut keliling dalam lingkaran sebesar $23,5 \%$, (2) kesalahan dalam konsep hubungan sudut pusat dan sudut keliling dalam lingkaran sebesar $41,1 \%$, (3) kesalahan dalam konsep panjang busus sebesar $17,6 \%$ dan (4) kesalahan dalam konsep luas juring sebesar 29,4\%. Kesalahan konsep siswa kemampuan matematika sedang sebesar 35\% dengan bentuk-bentuk kesalahan siswa yang dilakukan adalah (1) Kesalahan dalam konsep sifat sudut keliling dalam lingkaran sebesar 9,5\%, (2) kesalahan dalam konsep hubungan sudut pusat dan sudut keliling dalam lingkaran sebesar $12,6 \%$, (3) kesalahan dalam konsep panjang busus sebesar $11,1 \%$ dan (4) kesalahan dalam konsep luas juring sebesar 20,6\%. Kesalahan konsep siswa kemampuan matematika tinggi sebesar 21,4\% dengan bentukbentuk kesalahan siswa yang dilakukan adalah (1) Kesalahan dalam konsep sifat sudut keliling dalam lingkaran sebesar 0\%, (2) kesalahan dalam konsep hubungan sudut pusat dan sudut keliling dalam lingkaran sebesar 7,1\%, (3) kesalahan dalam konsep panjang busus sebesar $7,1 \%$ dan (4) kesalahan dalam konsep luas juring sebesar $14,2 \%$.

Berdasarkan hasil tes, siswa SH1 yang memiliki tingkat kemampuan matematika rendah melakukan kesalahan pada konsep panjang busur dan luas juring pada soal nomor 2. Berdasarkan hasil wawancara dengan siswa $\mathrm{SH} 1$, hal ini terjadi karena siswa tersebut tidak memahami konsep panjang busur dan luas juring. Siswa SH1 menuliskan panjang busur sebesar $100^{\circ}$ dengan langkah-langkah penyelesaian yang dia sendiri bingung dan tidak mengerti.

Siswa ES1 yang memiliki tingkat kemampuan matematika sedang melakukan kesalahan konsep luas juring. Berdasarkan hasil wawancara dengan siswa ES1, hal ini terjadi karena siswa tersebut tidak mengerti konsep luas juring. Siswa tersebut hanya menghafal rumusrumus tanpa memahami konsep secara jelas. Siswa MM1 yang memiliki kemampuan matematika tinggi tidak melakukan kesalahan konsep.

Kesalahan operasi dalam penelitian ini adalah kesalahan dalam melakukan perhitungan aljabar. Kesalahan operasi yakni kesalahan dalam perhitungan yang dilakukan siswa kemampuan matematika rendah sebesar $0 \%$. Kesalahan operasi siswa kemampuan matematika sedang sebesar $8 \%$. Kesalahan operasi siswa kemampuan matematika tinggi sebesar 21,4\%.

Berdasarkan hasil tes, siswa MM1 melakukan kesalahan perhitungan $2 \times 72^{\circ}=142^{\circ}$ seharusnya $2 \times 72^{\circ}=144^{\circ}$ pada butir soal 1 , dan $22 \times 7=156$ seharusnya $22 \times 7=154$ pada butir 3. Berdasarkan hasil wawancara, hal ini terjadi karena siswa tersebut terlalu terburu-buru dalam mengerjakan soal.

Kesalahan prinsip dalam penelitian ini adalah ketidakmampuan siswa dalam menghubungkan beberapa konsep yakni konsep sudut dalam segitiga, luas persegi dan luas segitiga. Kesalahan prinsip siswa kemampuan matematika rendah sebesar $94,1 \%$ dengan bentuk-bentuk kesalahan siswa yang dilakukan adalah adalah (1) Kesalahan dalam konsep sudut dalam segitiga sebesar $64,7 \%$, (2) kesalahan 
dalam konsep luas persegi sebesar 17,6\% dan (3) kesalahan dalam konsep luas segitiga sebesar $11,7 \%$. Kesalahan prinsip siswa kemampuan matematika sedang sebesar $60,3 \%$ dengan bentuk-bentuk kesalahan siswa yang dilakukan adalah(1) Kesalahan dalam konsep sudut dalam segitiga sebesar $26,9 \%$, (2) kesalahan dalam konsep luas persegi sebesar $22,2 \%$ dan (3) kesalahan dalam konsep luas segitiga sebesar $11,1 \%$. Kesalahan prinsip siswa kemampuan matematika tinggi sebesar $28,5 \%$ dengan bentukbentuk kesalahan siswa yang dilakukan adalah (1) Kesalahan dalam konsep sudut dalam segitiga sebesar $7,1 \%$, (2) kesalahan dalam konsep luas persegi sebesar $21,4 \%$ dan (3) kesalahan dalam konsep luas segitiga sebesar $0 \%$.

Berdasarkan hasil tes, siswa ES1 yang memiliki tingkat kemampuan matematika sedang melakukan kesalahan konsep luas persegi pada soal nomor 2. Siswa ES1 menuliskan nilai jarijari atau $r=60^{\circ}$. Berdasarkan hasil wawancara, siswa tersebut tidak memahami konsep luas persegi. Meskipun demikian, siswa ES1 tahu mengenai bentuk bangun persegi. Siswa ES1 juga melakukan kesalahan konsep luas segitiga dalam mencari luas tembereng. Siswa ES1 menuliskan bahawa luas tembereng adalah sama dengan panjang busur pada soal nomor 3 . Berdasarkan hasil wawancara dengan siswa ES1, hal ini terjadi karena siswa tersebut tidak tahu konsep dalam mencari luas tembereng. Meskipun demikian, siswa ES1 tahu mengenai bentuk dari tembereng yang dimaksud dalam soal.

Siswa MM1 yang memiliki tingkat kemampuan matematika tinggi melakukan kesalahan konsep luas persegi. Berdasarkan hasil wawancara, hal ini terjadi karena siswa tersebut lupa mengenai konsep luas persegi.

Berdasarkan hasil tes, siswa ES1 yang memiliki tingkat kemampuan matematika sedang melakukan kesalahan konsep luas persegi pada soal nomor 2. Siswa ES1 menuliskan nilai jarijari atau $r=60^{\circ}$. Berdasarkan hasil wawancara, siswa tersebut tidak memahami konsep luas persegi. Meskipun demikian, siswa ES1 tahu mengenai bentuk bangun persegi. Siswa ES1 juga melakukan kesalahan konsep luas segitiga dalam mencari luas tembereng. Siswa ES1 menuliskan bahawa luas tembereng adalah sama dengan panjang busur pada soal nomor 3 . Berdasarkan hasil wawancara dengan siswa ES1, hal ini terjadi karena siswa tersebut tidak tahu konsep dalam mencari luas tembereng. Meskipun demikian, siswa ES1 tahu mengenai bentuk dari tembereng yang dimaksud dalam soal.

Siswa MM1 yang memiliki tingkat kemampuan matematika tinggi melakukan kesalahan konsep luas persegi. Berdasarkan hasil wawancara, hal ini terjadi karena siswa tersebut lupa mengenai konsep luas persegi.

\section{Simpulan dan Saran}

\section{Simpulan}

Berdasarkan hasil penelitian dan pembahasan, dapat disimpulkan bahwa:

1. Kesalahan fakta siswa kemampuan matematika rendah sebesar $41,1 \%$, siswa kemampuan matematika sedang sebesar 49,2\%, dan siswa kemampuan matematika tinggi sebesar $42,8 \%$.

2. Kesalahan konsep siswa kemampuan matematika rendah sebesar $70,1 \%$, siswa kemampuan matematika sedang sebesar $35 \%$ dan siswa kemampuan matematika tinggi sebesar 21,4\%.

3. Kesalahan operasi siswa kemampuan matematika rendah sebesar $0 \%$, siswa kemampuan matematika sedang sebesar $8 \%$ dan siswa kemampuan matematika tinggi sebesar 21,4\%.

4. Kesalahan prinsip siswa kemampuan matematika rendah sebesar $94,1 \%$, siswa kemampuan matematika sedang sebesar $60,3 \%$ dan siswa kemampuan matematika tinggi sebesar $28,5 \%$.

5. Faktor-faktor penyebab siswa melakukan kesalahan fakta pada siswa kemampuan matematika rendah yakni terlalu terburuburu dan tidak memahami satuan yang dimaksud dalam soal, sedangkan siswa kemampuan matematika sedang dan tinggi melakukan kesalahan fakta disebabkan oleh terlalu terburu-buru dan kurang memperdulikan pentingnya menuliskan satuan meskipun para siswa mengetahui satuan yang dimaksud dalam soal.

6. Faktor-faktor penyebab siswa melakukan kesalahan baik siswa kemampuan matematika rendah, sedang dan tinggi adalah karena ketidakpahaman siswa dalam konsep-konsep materi lingkaran.

7. Faktor-faktor penyebab siswa melakukan kesalahan operasi baik siswa kemampuan matematika sedang dan rendah adalah 
karena ketidaktelitian siswa dalam mengerjakan soal. Siswa kemampuan matematika rendah tidak melakukan kesalahan operasi.

8. Faktor-faktor penyebab siswa melakukan kesalahan prinsip baik siswa kemampuan matematika rendah, sedang dan tinggi adalah karena siswa tidak memahami konsep prasyarat dalam materi lingkaran dan hanya terpaut pada contoh soal yang diberikan guru.

\section{Saran}

Berdasarkan kesimpulan di atas, maka peneliti menyarankan beberapa hal sebagai berikut.

1. Siswa hendaknya memiliki buku paket selain buku yang dibagikan di sekolah.

2. Sebaiknya siswa sering berlatih contoh soal yang bervariasi selain soal yang diberikan oleh guru.

3. Siswa diharapkan selalu teliti dalam mengerjakan soal untuk menghindari kesalahan yang terjadi akibat ketidaktelitian.

\section{Daftar Pustaka}

Abdurrahman, Mulyono (2003). Pendidikan Bagi Anak Berkesulitan Belajar. Jakarta: Rineka Cipta.

Aisyah, Nyimas (2007). Pengembangan Pembelajaran Matematika di SD. Jakarta: Departeman Pendidikan Nasional.

Hidayat, Badi Rahmad (2013). Analisis Kesalahan Siswa dalam Menyelesaikan Soal pada Materi Ruang Dimensi Tiga Ditinjau dari Gaya Kognitif Siswa. Jurnal Pendidikan Matematika Solusi Universitas Sebelas Maret Volume 1, No. 1.

Kamarullah (2005). Analisis Kesalahan Mahasiswa D-2 PGMI IAIN Ar-Ramiry Banda Aceh Tentang Geometri di Madrasah Ibtidaiyah beserta Alternatif Pembelajarannya. Seminar Tesis Pascasarjana Pendidikan Matematika Universitas Negeri Surabaya.

Moleong, Lexy J. (2006). Metode Penelitian Kualitatif. Bandung: Remaja Rosdakarya.
Munandar, Utami (2002). Pengembangan Kreativitas Anak Berbakat. Jakarta: Rineka Cipta.

Mahendra, I Wawan Eka. (2007). Pengaruh Pembelajaran Kontekstual dan Gaya Berpikir Terhadap Prestasi Belajar Matematika. Singaraja: Undiksha.

Qulfasia, M. (2015). Pengaruh Model Pembelajaran ARIAS dengan Aetting Kooperatif JIGSAW Terhadap Hasil Belajar Matematika Siswa Kelas VIII SMP Negeri 4 Kendari. Skripsi Universitas Halu Oleo: Tidak Diterbitkan.

Poerwadarminta, W.J.S. (2011). Kamus Besar Bahasa Indonesia. Jakarta: Balai Pustaka.

Rahayu, Wa Ode J. (2015). Analisis Kesalahan Konsep Matematika Siswa Kelas X SMA Negeri 2 Kendari pada Materi Eksponen, Logaritma dan Nilai Mutlak. Skripsi Pendidikan Matematika Universitas Halu Oleo Kendari.

Rofiki, Imam (2013). Profil Pemecahan Masalah Geometri Siswa Kelas Akselerasi SMP Negeri 1 Surabaya Ditinjau dari Tingkat Kemampuan Matematika. Prosiding Seminar Nasional Matematika dan Aplikasinya Departemen Matematika Fakultas Sains dan Teknologi Universitas Airlangga Volume 1, 300-310.

Rusman. (2010). Model-Model Pembelajaran, Mengembangkan Profesionalisme Guru. Jakarta: PT RajaGrafindo Persada.

Sudjono, Anas. (2009). Pengantar Statistik Pendidikan. Jakarta. Raja Grafindo Persada.

Slameto (2003). Belajar dan Faktor-Faktor yang Mempengaruhinya. Jakarta: Rineka Cipta.

Sudijono, Anas (2008). Pengantar Evaluasi Pendidikaan. Jakarta: Raja Grafindo Persada

Sugiyono (2011). Metode Penelitian Kuantitatif, Kualitatif, dan $R \quad \& \quad B$. Bandung: Alfabeta. 
Jurnal Penelitian Pendididikan Matematika Volume 7 No.2 Mei 2019

Ulifa, Siti Nur (2014). Hasil Analisis Kesalahan

Siswa dalam Menyelesaikan Soal Matematika pada Materi Relasi. Jurnal

Pendidikan Matematika Sekolah Tinggi

Keguruan dan Ilmu Pendidikan PGRI

Sidoarjo Volume 2, No. 1. ISSN: 2337 8166. 